\title{
Quantitative and Qualitative Characteristics of Boer x Local Goats Crossbred
}

\author{
Agus Budiarto ${ }^{1 *}$, Agus Susanto ${ }^{2}$, Gatot Ciptadi ${ }^{1}$, Ardyah Ramadhina Irsanti Putri $^{1}$ and Mochamad Aris \\ Sunaryo ${ }^{1}$
}

\author{
${ }^{1}$ Faculty of Animal Husbandry, Brawijaya University, Malang, Indonesia \\ ${ }^{2}$ Faculty of Animal Science, Jenderal Soedirman University, Purwokerto, Indonesia \\ *Corresponding author email: agusfpt@ub.ac.id
}

\begin{abstract}
The Boercang goat is a crossbred between male Boer goat and local female goat. This study was aimed to analyze the production and physical performances of Boercang goats during the weaning up to the age of one year. Thirty nine males and 37 females goats aged $3-12$ months were used in the study. Body weight, daily weight gain, coat colour pattern, horn, ears, nose shape and birth type were recorded during study. The data obtained were calculated for the means, standard deviation (SD), and coefficient of variation (CV) and the analysis was descriptive. Student t test was performed to compare differences between groups of age and between group of sex. Field observations showed that the qualitative characteristics of Boercang such as body colour, horns, ears, and nose shape were $50 \%$ identical with the characteristics of male Boer. The average body weight of the male Boercang goats was $23.02 \pm 1.56 \mathrm{~kg}$ whereas the female Boercang goats was $21.86 \pm 1.63 \mathrm{~kg}$. Body weight gain was affected by age and birth type. The conclusion is that the genetic superiority of the qualitative characteristics of the Boer goats is still expressed in the offspring although it varies; for the characteristics of horns, colour patterns and ears still contribute more than $50 \%$. The appearance of superior quantitative traits from the male Boer goat during the period of weaning up to one year of age both based on the birth type and offspring sex tends to be higher than the appearance of local goat.
\end{abstract}

Keywords: Boercang goats, body weight, daily weight gain, vital statistics, qualitative traits

Abstrak. Kambing Boercang merupakan kambing persilangan antara kambing boer jantan dan kambing betina lokal. Penelitian yang dilakukan untuk mengetahui performans produksi dan performans fisik Kambing Boercang, umur lepas sapih sampai dengan umur 1 tahun. Kambing yang digunakan adalah 76 ekor teridiri dari 39 ekor jantan dan 37 ekor betina umur 3 - 12 bulan. Metode yang digunakan dalam penelitian ini adalah metode studi kasus. Variable yang diamati bobot badan, pertambahan bobot badan, pola warna, tipe kelahiran, Data yang diperoleh dihitung nilai rataanya, standar deviasi (SD), dan koefisien keragaman (KK), kemudian dianalisis secara descriptive. Uji t dilakukan untuk membandingkan rataan antar grup umur dan antar grup jenis kelamin. Hasil pengamatan lapang menunjukkan bahwa karakteristik kualitatif Boercang seperti warna tubuh, tanduk, telinga, dan bentuk hidung, $50 \%$ masih mengikuti karakter dari jantan boer. Rata-rata bobot badan Kambing Boercang jantan adalah 23,02 $\pm 1,56 \mathrm{~kg}$ dan Kambing Boercang betina adalah $21,86 \pm 1,63 \mathrm{~kg}$. Pertambahan bobot badan didasarkan pada berbagai tingkat usia dan jenis kelahiran. Kesimpulan yang dapat diambil adalah Penampilan keunggulan sifat kualitatif pejantan kambing Tipe Pedaging (Boer), masih ditunjukkan pada keturunannya meskipun bervariasi, untuk sifat tanduk, pola warna dan telinga masih memberikan kontribusi lebih dari 50 \%. Penampilan keunggulan sifat kuantitatif dari pejantan kambing tipe pedaging (Boer), pada kambing umur sapihan sampai umur satu tahun baik berdasarkan tipe kelahiran maupun jenis kelamin keturunannya, cnderung lebih tinggi di bandingkan penampilan produksi kambing local.

Kata kunci: Kambing Boercang, bobot badan, pertambahan bobot badan, statistik vital, sifat kualitatif

\section{Introduction}

The Boer goat is a goat originating from South Africa, classified as a meat type goat. Boer goats have characteristics of curved up and back horns, wide and hanging ears, convex nose, relatively short to medium hair and a basic colour of white and usually with a combination of brown or maroon from the neck to the head, and they have rapid growth. Boer goats give birth 3 times in 2 years and have good quality of meat production (Nasich, 2012). Local goats are considered to be easy to adapt to the environment, quickly sexually matured and are easily crossed with other goats. They 
also adaptable to low-quality feeding. According to Subandriyo (2004), there are two dominant goat families in Indonesia, i.e. Ettawah crossbred and Kacang goats. Kacang goats have high fertility with the average litter size ranging 1-4 and have the ability to adapt well to unfavorable environmental conditions (Sulastri et al., 2014).

Crossbreeding is an effort to combine two or more traits into a crossbred offspring, with the aim of increasing the productivity of local goats through planned matting with livestock that have particular advantages. The Boercang goat is the result of crossbreeding between male non-purebred Boer goats and female local goats. Crossing Boer goats with local goats have been widely practiced by smallholder farmers. Crossing Boer goats with local ones are expected to improve the productivity of Indonesian local goats both their growth and meat production.

The production performance of Boercang goats can be determined from the size of their vital statistics and body weight. Livestock vital statistics is a measure of the animal's body whose increments are linearly related to each other. Livestock body weight and vital statistics are indicators of livestock productivity. Body weight will increase according to the age of the livestock. The increase in body weight will be followed by an increase in the size of the vital statistics. The body measures increase with increasing body weight of livestock Victori et al. (2016). The body size of livestock can provide an exterior judgement and can be used as a basic guideline for selection in livestock breeding programs. Some vital statistics of livestock were reported to be correlated with some economically traits and important traits and to some degrees the correlation is genetics (Susanto et a; 2018). The information of genetic correlation between traits can be utilized in a breeding program through indirect selection.
Boercang goat productivity varies between regions. This is due to differences in environmental conditions and is influenced by differences in the genes proportion of Boercang males (F1 and or F2). Production performance of goats is part of quantitative trait which is sensitive to environmental influences. In addition, Boercang goats aged up to 1 year are also within growth period, so the need for nutrition (quantity and quality) is crucial to express their superior characteristics. Variations in production performance, especially in crossbred goats as a result of these environmental factors, are the key to how much superior characteristics of Boer male breeds can contribute to their offspring.

\section{Materials and Methods}

The study used 76 males and females Boer cross-bred goats ranging from weaning up to one year of age. The study was a survey applying purposive sampling. Individual body weight (BW) and average daily gain (ADG) were measured and qualitative characteristics (coat colour, horn, ears and nose shape) were recorded for the study. The data analysis used in this study is descriptive by computing means $(\bar{x})$ and standard deviation (SD) and the coefficient of variation (CV). T-test comparison was used to evaluate the means difference between groups of age (3-6 month versus 6-12 month) as well as between group of sex. The mean $(\bar{x})$, standard deviation and coefficient of variation were calculated using the following formula:

$$
\begin{aligned}
& \bar{x}=\frac{\sum x i}{n} \\
& s d=\sqrt{\frac{\sum x i^{2}-\frac{1}{n}(\Sigma x i)^{2}}{n-1}} \\
& C V=\frac{s d}{\bar{x}} \times 100 \%
\end{aligned}
$$


where:

$\bar{x} \quad=$ means of quantitative characteristics (body weight, ADG)

$x_{i} \quad=\mathrm{i}^{\text {th }}$ observation of BW and ADG

$n \quad=$ number of samples

sd $\quad=$ Standard deviation

$C V=$ Coefficient of Variation

\section{Results and Discussion}

\section{Qualitative Traits}

The superiority of the males is passed down to their offspring, even though the males used are no longer pure breed, i.e., F1 or F2 crossbred. The characteristics of the horns, ears and nose shape are still above 50 percent similar to the pure breed of Boer goats, because the characteristics of the curved up horn and flat or gentle curve nose shape are also owned by local females; the percentage of being wide ears is still quite high because in Boer goats the ears are generally drooping and wide, while local goats have narrow ears. Qualitative characteristics of Boer crossbred including coat colour, horns, ears and nose shape are presented in Table 1.

The characteristic features of Boer goat is the reddish-brown colour on the head and neck (Wu et al., 2006) and the other parts of the body are dominated by white. As shown in Table 1, male and female Boercang goats aged 3-12 months majority of 29 heads (38.2\%) have white-brown body colour with a brown head colour, followed by brown body colour with a brown head of 4 heads (5.3\%), black white body colour with black head of 28 heads (36.8\%), white coat colour with white head of 13 heads $(17.1 \%)$ and black body colour with black head of 2 heads(2.6\%). Most of the coat colours of the crossbred goats are inherited from the Boer male which caries mostly dominant gene controlling coat colour. Variations that occur as in Table 1 can be traced that the offspring were obtained from 3 Boer males crossed with local females. The 3 male Boer goats used in crossing have white-brown coat colour with brown head, and only one Boer male has white-black coat colour with black head. Sixty seven heads (88.2\% of goats both male and female Boercang goats at the age of 3-12 months had horns and 9 heads (11.8\%) did not have horns. However, being horned during 3-4 months of age is not the indicator that the animals do not grow horns because they are still in a growing period and the horns will grow later. Boercang goats with long drooling down ears were 50 heads (65.8\%) and with short width ears were 26 heads (34.2\%). Most (59.2\%, 45 heads) of the Boercangs have convex nose while the rest (40.1\%, 31 heads) had a flat nose.

The exterior characteristics being the black colour and the absence of horns is suggested to be inherited from the Boer male. On the other hand, the patter on black coat and head colour are similar to that of local goats (or Ettawa cross). According to Henkel et al. (2019), the mammalian coat colour is determined by the distribution of two types of melanin pigment,

Table 1. Qualitative characteristics of female Boercang goats

\begin{tabular}{llc}
\hline Traits* & Description & Frequency (\%) \\
\hline Coat colour & White-brown coat (brown head) & 38.2 \\
& Brown coat (brown head) & 5.3 \\
& White-black coat (Black head) & 36.8 \\
& White coat (White head) & 17.1 \\
Horns & Black coat (Black head) & 2.6 \\
& Horned & 88.2 \\
Ears & No horn & 11.8 \\
& Long, drooping & 65.8 \\
Nose shape & Short, wide & 34.2 \\
& Convex & 59.2 \\
\end{tabular}

*) Number of sample: 76 heads 
Agus Budiarto et al./Animal Production. 23(2):77-83, 2021

Accredited by Kemenristek Dikti No 32a/E/KPT/2017. ISSN 1411-2027

Table 2. Means and Standard Deviation of Body Weight of Boercang

\begin{tabular}{|c|c|c|c|c|c|c|}
\hline Description & (3-4 mo) & $(5-6 \mathrm{mo})$ & $(7-8 \mathrm{mo})$ & (9-10 mo) & $(11-12 \mathrm{mo})$ & Average \\
\hline \multicolumn{7}{|l|}{ Males } \\
\hline BW (kg) & $16.90 \pm 1.26$ & $19.43 \pm 0.98$ & $22.50 \pm 2.12$ & $25.25 \pm 1.71$ & $31.00 \pm 1.73$ & $23.02 \pm 1.56$ \\
\hline CV (\%) & 7.46 & 5.02 & 9.43 & 6.76 & 5.59 & 6.85 \\
\hline $\mathrm{N}^{1}$ & 21 & 7 & 2 & 4 & 3 & \\
\hline \multicolumn{7}{|l|}{ Females } \\
\hline BW (kg) & $14.31 \pm 2.25$ & $17.55 \pm 1.29$ & $21.50 \pm 1.29$ & $25.71 \pm 1.60$ & $30.25 \pm 1.71$ & $21.86 \pm 1.63$ \\
\hline CV (\%) & 15.73 & 7.37 & 6.00 & 6.24 & 5.65 & 8.20 \\
\hline $\mathrm{N}^{2}$ & 13 & 11 & 4 & 7 & 4 & \\
\hline
\end{tabular}

${ }^{1}$ Total samples of male: 37

${ }^{2}$ Total samples of female: 39

namely eumelanin, which is associated with black or brown, and pheomelanin, which is associated with red or yellow. The dominant allele at the extension locus will produce black coat colour, while the recessive allele produces red or yellow pigmentation.

On the other hand, the dominant allele at the agouti locus produces pheomelanin pigmentation, while the recessive allele causes uniform black coloration. There are several genes that are suggested to be related to the colour of goat hair, so it is not certain what genes determine the colour of goat hair (Badaoui et al. 2011). One of these genes is caprine agouti which has been analyzed by some researchers such as Henkel et al (2019), Li et al. 2010, Badaoui et al. 2011 and Akis et al. 2012).

\section{Quantitative Characteristics of Crossbred Goats}

Body weight of Boercang goats aged 3-12 months of the present study are presented in Table 2.

As expected, the body weight of Boercang goats increased as the animals grow older for both sexes. Across different age groups, male Boercang goats was heavier than the females one ( 23.02 versus $21.86 \mathrm{~kg}$ ). The difference of body weight between male and females is attributed to hormonal characteristics between sexes especially the secretion rate of growth hormones, such as testosterone produced by testes in males (Ashari et al., 2015).
Testosterone affects the metabolic rate in the body of livestock so that male cattle are more efficient in using food when compared to female animals, which results in the greater growth rate of males than females. In female Boercang goats, the average coefficients of variation were $15.73 \%, 7.37 \%, 6.00 \%, 6.24 \%$, and $5.65 \%$ with a average coefficient of variation across age groups of $8.20 \%$ compared to $6.85 \%$. This shows that female Boercang goats are more diverse than male Boercang goats which could be due to non-genetics factors such as feeding.

The average ( \pm standard deviation) body weight of male and female Boercang goats of the present study at the age of 5-6 months were $19.43 \pm 0.98 \mathrm{~kg}$ and $17.55 \pm 1.29 \mathrm{~kg}$. Compared to that of Kacang and Boerka goats, the Boercang goats are heavier. Elieser (2015) reported that the average body weight of Kacang, Boerka and Boer goats at the age of 6 months were $11.96 \pm 1.841 \mathrm{~kg}, 13.76 \pm 1.768 \mathrm{~kg}$ and $19.78 \pm 2.176 \mathrm{~kg}$, respectively. Boercang goats body weights are consistently higher than Kacang goats at various ages. Generally male and female Boercang goats aged 5-6 months are higher than Kacang goats and Boerka goats, but lower than Boer goats. Boerawa goats of grade 1 and grade 2 at weaning (usually 3 months old) have an average body weight of $19.89 \mathrm{~kg}$ and $19.67 \mathrm{~kg}$ (Sulastri et al., 2014). However Nasich (2012) reported lighter body weight of Boerawa goats of grade 1 at weaning i.e. $16.4 \mathrm{~kg}$ (single), $12.47 \mathrm{~kg}$ (twins) and 10.511 
$\mathrm{kg}$ (triplets). The average body weight of male and female Boercang goats aged 5-6 months was lower than the average body weight of Boerawa goats grade 1 and Boerawa grade 2 at weaning (3 months).

The average body weight of male Boercang goats aged 11-12 months was $31.00 \pm 1.73$ while at the same age the male Boerawa grade 1 goats had a body weight of $42.49 \pm 6.15$ (Sulastri et al., 2014). According to Victori et al. (2016), animals have different stages (fast and low) of growth during their life.

The average daily weight gain (ADG) of Boercang goats based on birth type and sex can be seen in Table 3.

Post-weaning daily weight gain is the average daily weight gain starting from weaning until the age of one year. Table 3 shows that the type of birth and sex affect the growth rate of goats. Naturally the growth rate of male goats is higher than that of female goats. In addition, the growth rate of crossbred animals (crossing between Boer goats and local goats) produces offsprings that inherit superior characteristics from both parents. Genetically, the crossbred goats will have a production performance above the average of their parents due to heterosis effects (Meza-Herrera et al., 2019). The daily weight gain of the present study was lower than the previous study reported by Ginting and Mahmilia (2008). They reported that the daily body weight gain of
Boerka goats for single births were 115-141 $\mathrm{g} / \mathrm{head} /$ day and twin births were 93-101 $\mathrm{g} / \mathrm{head} /$ day. The daily weight gain according to sex were 106-126 g/head/day for males and 77$112 \mathrm{~g} / \mathrm{head} /$ day for females. These differences are controlled by both genetics and the environment. One of the environmental factors affecting daily weight gain was feeding management Nasich (2012).

Body weight is influenced by many genes (Wang et al., 2016; Zhang et al., 2013), showing massive variations in allele combinations and resulting in differences in the expression of genes controlling body weight. Gene expression in this case is influenced by genetic variation, with a focus on variation between individuals (Williams et al., 2007). The crossbreeding results between Boer and Jawarandu goats achieved the highest hybrid vigour value when mated to F1 in this study. The hybrid vigour value will be optimal when the two parents are not related or come from two different breeds (Bourdon, 2014).

The collected field data of the present study shows that the birth weight of Boercang goats was $2.4 \mathrm{~kg}$ for females with single birth type and $2.8 \mathrm{~kg}$ for males with single birth type. The two data were obtained directly by weighting each animal on day 0 (right after delivered). The birth weight was heavier compared to Kacang and Boerka goats but lower than the birth weight of the Boer goat.

Table 3. Average daily weight gain according to birth type and sex

\begin{tabular}{lrcc}
\hline \multicolumn{1}{c}{ Descriptions } & $\mathrm{N}$ & Mean $\pm \mathrm{SD}(\mathrm{kg} / \mathrm{d})$ & Coefficient of Variation $(\%)$ \\
\hline Birth type & & & \\
$\quad$ Single & 45 & $0.081 \pm 0.015$ & 18.96 \\
$\quad$ Twins & 32 & $0.076 \pm 0.009$ & 12.17 \\
Sex & & & 13.89 \\
$\quad$ Males & 37 & $0.085 \pm 0.012$ & 16.07 \\
$\quad$ Females & 39 & $0.073 \pm 0.012$ & 6.08 \\
Birth type by sex & & & 12.34 \\
$\quad$ Single male & 7 & $0.103 \pm 0.006$ & 8.94 \\
$\quad$ Single female & 4 & $0.089 \pm 0.011$ & 8.30 \\
$\quad$ Twins male & 14 & $0.081 \pm 0.007$ & \\
$\quad$ Twin female & 9 & $0.073 \pm 0.006$ & \\
\end{tabular}


According to Ginting (2005), the birth weight of the Kacang goats are $1.5-2.0 \mathrm{~kg}$ and the Boerka goats are $2.2-2.8 \mathrm{~kg}$. According to Syawal (2010), the average birth weight of Boer goats is $2.94 \pm 0.87 \mathrm{~kg}$. Wu et al. (2006) stated that the birth weight of Boer lambs ranged from 3-4 kg with males was about 0.5 heavier than females. Nasich (2012) reported that body weight gain of the same breed was $122.97+43.68 \mathrm{~g} /$ day for males and $108.16+36.35 \mathrm{~g} /$ day for females.

The birth weight gain according to birth types of single, twins, triplets and quadruplets respectively were $141.2+41.82 \mathrm{~g} /$ day, $105.93+34.78 \mathrm{~g} /$ day, $87.71+25.27 \mathrm{~g} /$ day and 83 , $87+30.36 \mathrm{~g} /$ day. Birth weight gain may vary within a population due to the influence of genetics, health status, nutrition, breeding age and management system. The relatively high growth rate is associated with the high birth weight of Boercang goats. The rate of lamb growth is largely determined by the adult size capacity of both parents. The use of Boer males, which have large body size, is a major contributor to the high growth rate of Boerka goats (Ginting and Mahmilia, 2008).

The results of the analysis showed that the increase of body weight of Boercang goats decreased as the age increased. According to Ginting and Mahmilia (2008), the increase in body weight of Kacang goats aged $>3-6$ months was 42-69 g/day, age >6-9 moths was $57 \mathrm{~g} /$ day, and age $>9-12$ months was $38 \mathrm{~g} /$ day. According to Syawal (2010) reported that the Boer goat was weaned ( 3 months old) with a daily weight gain of $110 \mathrm{~g} /$ day. The post weaning daily gain of Grade 1 of Boerawa goats was $0.07 \pm 0.01$ $\mathrm{kg} /$ day (Sulastri et al., 2014). These data inconsistency are greatly influenced by genetics and the environment. In this study, pure and selected Boer male goats were crossed with local female goats so that the progeny will have high daily weight gain and growth genetically inherited from their parents. Meanwhile, the mating between unselected Boer goats local female goats had lower growth rates than pure and selected Boer rams. The post-weaning growth rate will experience a slowdown, even with high feed nutrition, compared to the growth during pre-weaning period (Saleem et al., 2017).

The statistical test of both age groups (3-6 months and 6-12 months) and sex groups showed a highly significant difference $(p<0.01)$ in both BW and ADG traits. This indicates that the fast-growing trait shown by live weight and daily weight gain are inherited from Boer males and is still present in crossed Boer goats. Boer goats have superior characteristics as meat producer because of their high growth rate and body weight. Birth weight of Boer goats is reported to range from $3-4 \mathrm{~kg}$, with weaning weights ranging from $20-25 \mathrm{~kg}$. At the age of 1 year, Boer males reach weigh of up to $50-70 \mathrm{~kg}$ (Lu, 2001). It was also reported that Boer goats can grow with an average daily weight gain of $0.145-0.235 \mathrm{~kg}$ per day (Menezes et al., 2016; Brand et al., 2017).

\section{Conclusions}

The superiority of the qualitative characteristics of the Boer male goats is still majority shown in the offspring (for the characteristics of horns, colour patterns and ears) although the results were varied. The quantitative traits of the offspring from the Boer rams, in weaning up to the age of one year both based on the birth type and sex of the offspring tends to be higher than those of local goats.

\section{References}

Akis, I, K Oztabak, FE Gursel, C Un. 2012. Goat Agouti gene polymorphism and its association with coat color in indigenous Turkish goat breeds. Vet Med Zoot. 60:3-6.

Ashari, M, RRA Suhardiani, and R Andriati. 2015. Tampilan Bobot Badan dan Ukuran Linier Tubuh Domba Ekor Gemuk pada Umur Tertentu di Kabupaten Lombok Timur Performance of the Body Weight and the Linear Body Size of the Certain Age of Fat-Tailed Sheep in East Lombok 
Regency. Jurnal IImu Dan Teknologi Peternakan Indonesia Volume, 1(1), 24-30.

Badaoui, B, M D'Andrea, F Pilla, J Capote, A Zidi, J Jordana, A Ferrando, JV Delgado, A Martinez, O Vidal, and M Amills. 2011. Polymorphism of the goat Agouti signaling protein gene and its relationship with coat color in Italian and Spanish breeds. Biochem Genet. 49:523-532.

Brand, TS, DA Van Der Merwe, E Swart, and LC Hoffman. 2017. Comparing the effect of age and dietary energy content on feedlot performance of Boer goats. Small Ruminant Research, 157, pp.40-46.

Elieser, S. 2015. Performans Produksi Anak Hasil Persilangan Kambing Boer dan Kacang. In Prosiding Seminar Nasional Teknologi Peternakan dan Veterniner (pp. 315-323).

Ginting, SP. 2005. Sinkronisasi degradasi protein dan energi dalam rumen untuk memaksimalkan produksi protein mikrobia. Wartazoa, 15(1), 110.

Ginting, SP and F Mahmilia. 2008. Kambing Boerka kambing tipe pedaging hasil persilangan Boer $\mathrm{x}$ Kacang. Wartazoa, 18(3), 115-126.

Henkel, J, R Saif, V Jagannathan, C Schmocker, F Zeindler, E Bangerter, U Herren, D Posantzis, Z Bulut, P Ammann, and C Drögemüller. 2019. Selection signatures in goats reveal copy number variants underlying breed-defining coat color phenotypes. PLoS genetics, 15(12), p.e1008536.

Li, X, J Zhao, C Tang, R Zhou, G Zheng, L Li, X Guo. 2010. Sequencing of part of the goat Agouti Gene. Biochem Genet. 48:152-156.

Lu, CD. 2001. Boer goat Production: Progress and Perspective. In Proceedings of International Conference on Boer Goats. October 20-24, 2001. (pp. 1-11). Anshun, China.

Menezes, LM, WH Sousa, EP Cavalcanti-Filho, and LT Gama. 2016. Genetic parameters for reproduction and growth traits in Boer goats in Brazil. Small Ruminant Research, 136, pp.247256.

Meza-Herrera, CA, A Menendez-Buxadera, JM Serradilla, N Lopez-Villalobos, and F BaenaManzano. 2019. Estimates of genetic parameters and heterosis for birth weight, one-month weight and litter size at birth in five goat breeds. Small Ruminant Research, 174, pp.19-25.

Nasich, M. 2012. Produktivitas kambing hasil persilangan antara pejantan Boer dengan induk lokal (PE) periode prasapih. TERNAK TROPIKA Journal of Tropical Animal Production, 12(1), 5662.
Saleem, AM, Al Zanouny, and AM Singer. 2017. Growth performance, nutrients digestibility, and blood metabolites of lambs fed diets supplemented with probiotics during pre-and post-weaning period. Asian-Australasian journal of animal sciences, 30(4), p.523.

Subandriyo. 2004. Strategi Pemanfaatan Plasma Nutfah Kambing lokal dan Peningkatan Mutu Genetik Kambing di Indonesia. In Prosiding Lokakarya Nasional Kambing Potong. Bogor: Pusat Penelitian dan Pengembangan Peternakan.

Sulastri, S, S Sumadi, T Hartatik, and N Ngadiyono. 2014. Performans Pertumbuhan Kambing Boerawa di Village Breeding Centre, Desa Dadapan, Kecamatan Sumberejo, Kabupaten Tanggamus, Provinsi Lampung. Sains Peternakan: Jurnal Penelitian Ilmu Peternakan, 12(1), 1-9.

Susanto, A, VMA Nurgiartiningsih, and L Hakim. 2018. (Co) variance components and genetics parameter estimation for linear traits in Holstein cattle in Indonesia: traits related to foot/leg and udder. Archives animal breeding, 61(4), pp.491496.

Syawal, M. 2010. Karakterisktik Morfologi Dan Produksi kambing Boer, Kacang Dan Persilangannya pada Umur 0-3 Bulan (PraSapih). In Seminar Nasional Teknologi Peternakan dan Veteriner (Vol. 2010, pp. 616-620).

Victori, A, E Purbowati, and CMS Lestari. 2016. Hubungan antara ukuran-ukuran tubuh dengan bobot badan kambing Peranakan Etawah jantan di Kabupaten Klaten. Jurnal IImu-Ilmu Peternakan (Indonesian Journal of Animal Science), 26(1), 23-28.

Wang, X, J Liu, G Zhou, J Guo, H Yan, Y Niu, ... Y Chen. 2016. Whole-genome sequencing of eight goat populations for the detection of selection signatures underlying production and adaptive traits.

Williams, RBH, EKF Chan, MJ Cowley, and PFR Little. 2007. The influence of genetic variation on gene expression, 17, 1707-1716. https://doi.org/10.1101/gr.6981507.sp ecific

Wu, ZL, XL Li, YQ Liu, YF Gong, ZZ Liu, XJ Wang, TR $X i n$, and $Q$ Ji. 2006. The red head and neck of Boer goats may be controlled by the recessive allele of the MC1R gene. Animal Research, 55(4), 313-322.

Zhang, L, J Liu, F Zhao, H Ren, L Xu, J Lu, and L Du. 2013. GenomeWide Association Studies for Growth and Meat Production Traits in Sheep. PLoS ONE. https://doi.org/10.1371/journal. pone.0 066569 